\title{
Effect of synchronizing the rate degradation of protein and organic matter of feed base on rice by product on fermentation characteristic and synthesis protein microbial
}

\author{
Yenny .N.Anggraeny ${ }^{1,2}$, H. Soetanto ${ }^{3}$, Kusmartono ${ }^{3}$, Hartutik $^{3}$ \\ ${ }^{1}$ Post-graduate Program, Faculty of Animal Husbandry, Brawijaya University, Malang, Indonesia \\ ${ }^{2}$ Beef Cattle Research Institution, Grati, East Java, Indonesia \\ ${ }^{3}$ Faculty of Animal Husbandry, BrawijayaUniversity, Malang, Indonesia
}

\begin{abstract}
Low dry matter intake on rice straw due to nitrogen content of rice straw is low, so it is not able to support the growth of rumen microbes. Supplementation and synchronizing the rate degradation of protein and organic matter in the rumen can increase microbial protein production. The objective of this research was to determine the effect of synchronizing the rate degradation protein and energy of feed base on rice by product on fermentation characteristic and synthesis protein microbial on in vitro condition. Dietary treatments contained 3 level of synchrony indeks $(0.4 ; 0.5$ and 0.6$)$ that were derived from nutrient content and degradation parameters of feedstufs using nylon bag technique. This research was using randomized complete design. Synchronization index affected to the concentration of acetic acid $(P=0.007)$, propionic acid $(P=$ $0.020)$, butyric acid $(P=0.029), \mathrm{CH}_{4}(0.031)$ and ratio of $C_{2}: C_{3}(0.013)$. Improved synchronization index led to a decrease in acetic acid and $\mathrm{CH}_{4}$ and increase efficiency of microbial protein synthesis. This result indicated that the improvement of synchronization index can improve feed efficiency, reduce global warming and it can be expected to improve the productivity of livestock.
\end{abstract}

Key words: feed base on rice by product, fermentation characteristic, in vitro, synchrony indeks, synthesis protein microbial.

\section{Introduction}

Rice (Oryza zativa) is the main food crop in Indonesia so it has the highest harvesting area. Rice straw and rice bran are a by product of the rice plant and they were potential to be used as a ruminant feed. Harvesting area of the rice plant in Indonesia was 13.8 million Ha while on the island of Java was 6.5 million Ha (Anonimous, 2013). The production of rice bran is $8-12 \%$ of the rice grain, whereas an average production of rice grain in Indonesia is 4.9 Tons/ha. Production of rice straw is equivalent 3.86 Ton dry matter (DM)/Ha/crop if grown in wet land and $2.76 \mathrm{Ton} \mathrm{DM} / \mathrm{Ha} / \mathrm{crop}$ if grown in a dry land (Martawidjaya, 2003). Low dry matter intake on rice straw due to less capability to support the growth of rumen microbes that play in fermentative digestion especially in feedstuffs containing high crude fiber. Nitrogen $(\mathrm{N})$ content of rice straw is only 0.64 to $0.80 \%$ or equivalent to $4-5 \%$ protein, while the growth of rumen microbes need $1.28 \%$ of $\mathrm{N}$ or equivalent to $8 \%$ protein (Utomo, 2004). One of the ways to support the growth of rumen microbes is by supplementation. Rice bran can be used as a supplement on rice straw as forage.

The aim of supplementation is giving a nutrition for rumen microbes and the host. The synchronization degradation rate of energy and protein has been proposed as a method to increase ruminal MPS, improve efficiency of $\mathrm{N}$ usage and animal performance, decrease urinary $\mathrm{N}$ excretion (Sinclair et al., 1993; Cole et al., 2008) and fermentative carbon losses in $\mathrm{CO}_{2}$ and $\mathrm{CH}_{4}$ (Blummel et al., 1999 cyted by Chumpawadee et al., 2006). Synchronous supply of energy and protein to the rumen enhanced the efficiency of microbes in capturing $\mathrm{N}$ and use of ATP for microbial growth (Richardson et al., 2003), which implied synchronized feeds increased microbial protein production in the rumen and enhanced rumen fermentation efficiency, and thereby improved feed utilization and animal performance (Chumpawadee et al., 2006).

Formulation of feed with synchronization of availability of protein and energy in the rumen was developed by Sinclair et al. (1993). Sinclair et al. (1993) developed a parameter that called synchronization index. Synchronization index expressed as the ratio between the hourly degradability of nitrogen $(\mathrm{g} \mathrm{N})$ with organic matter $(\mathrm{kg} \mathrm{OM})$ or carbohydrates in the rumen where the highest value for the synchronization index is 1.0 .

This research was a preliminary study to evaluate the supplementation on of rice straw in ruminant animals with pay attention to synchronizing supply of protein and energy in the rumen on in vitro condition. 


\section{Material And Methods}

This research was conducted in Beef Cattle Research Station, Grati-East Java. The study consisted of two stages, the first stage was the determination of nutrients and the value of feed degradation parameter while the second stage was a research that examined the effect of synchronization index on feed based on rice by product to the fermentation characteristics and rumen microbial protein production on in vitro condition.

Research 1. Determination of nutrients and degradation parameters of feedstuffs. Feedstuffs that used to formulate a rations were rice straw, native grass, rice bran, cassava flour, palm kernel cake, coconut cake and molasses. Nutrient values include dry matter (DM), organic matter (OM), crude protein (CP), ether extract (EE) and crude fiber (CF) were determined according to AOAC (2009). Nitrogen free extract (NFE) was calculated according to Ibrahim (1988). Total Digestible Nutrient (TDN) value was determined according to Hartadi et al. (1986).

Ruminal degradation measurement using the nylon bag technique was carried out after two weeks adaptation period in a male Ongole Crossbred (body weight $647 \mathrm{Kg}$, fitted with permanent rumen cannula). Animal was offered elephant grass and commercial concentrate (60:40) that was calculated approximately at $3 \%$ DMI of live weight and given twice per day. Ruminal degradation measurement using 4 nylon bags to every feedstuffs. An empty nylon bags with a dimensions of $14 \times 8 \mathrm{~cm}^{2}$ heated in an oven at $45-50^{\circ} \mathrm{C}$ for 48 hours and then they were weighed. Nylon bags filled with feed ingredients as much as 5 grams of sample then they were tied with nylon thread. The next set of the nylon bag were tied to a plastic rope slap. They were placed in the rumen before feeding in the morning and they were taken back after an time interval incubation 2, $4,6,8,12,24$, and 48 hours for feed concentrates; 2, 4, 6, 12, 24, 48, and 72 hours for forage.

Nylon bags were taken from the rumen on each incubation time and they were washed under tap water until the water became clear. Nylon bag containing feed material residue was dried in an oven $60^{\circ} \mathrm{C}$. The residue was analysed of dry matter (DM), organic matter (OM) and crude protein (CP). To determine the content of water soluble material, bags representating 0 hours degradation also underwent the same washing procedure as the incubated bags. The value of feedstuffs degradation were the percentage of the sample weight that were missing after incubation with the initial sample weight. Further the value of feedstuffs degradation were used for the determination of degradation parameters using the formula developed by Ørskov and McDonald (1979) using a computer program developed by International Feed Resources Centre (2004). The formula developed by Ørskov and McDonald (1979) is as follows:

$$
\mathrm{P}=\mathrm{a}+\mathrm{b}\left(1-\mathrm{e}^{-\mathrm{ct}}\right)
$$

Description:

$\mathrm{P}=$ cumulative amount degraded at time $\mathrm{t}$.

$\mathrm{a}=$ fraction of feed material that rapidly soluble in the rumen (\%).

$\mathrm{b}=$ potentially degradable fraction in the rumen $(\%)$.

$\mathrm{c}=$ rate of degradation $(\% / \mathrm{h})$.

$\mathrm{t}=$ time (hours).

The variables observed in this study were 1) the fraction of protein and organic matters of feed that rapidly soluble in the rumen or $a$ value, 2) protein and organic matter of feed ingredients that insoluble but potential for degradation or $b$ value and 3) the rate of degradation of protein and organic matter or $c$ value.

Research 2. Effect of synchronization of degradation of protein and organic matter of feed based on rice by product to fermentation characteristics and rumen microbial protein production on in vitro condition. The material of this study was three of feed based on rice by product using feed ingredients such as rice straw, native grass, rice bran, cassava flour, coconut cake and palm kernel cake with synchronization index low (0.4) as P1, medium (0.5) as P2 and high (0.6) as P3. Determination of the value of synchronization index using the formula developed by Sinclair et al. (1993), as follows:

$$
\text { synchrony index }=25-\sum_{1-24} \frac{\sqrt{\left(25-\text { hourly } \frac{N}{O M}\right) 2}}{24}
$$

Description :

- Twenty five (25) is $25 \mathrm{~g} \mathrm{~N}$-protein/kg OM digested in the rumen, is assuming the optimum ratio for efficiency of the synchronization of microbial protein synthesis in the rumen ( Czerkawski 1986) .

- hourly N / OM is the quantity of nitrogen and organic matter degraded per hour. 
- synchronization with the index value of 1.0 indicates perfect synchronization between the supply of $\mathrm{N}$ - protein and energy during the day and the value of $<1.0$ indicated unsynchronization.

- Computer programs are modified by Sinclair et al . (1993) was used to calculate the N and OM supply from feed, this program requires input data including :

a. Content of DM, CP and OM of feedstuffs.

b. Value of soluble fraction ( a), potentially degradable fraction ( b ) and the rate of degradation ( c ) of OM and $\mathrm{CP}$ of feedstuffs.

c. The proportion of each constituent in the diet.

d. DM intake per day, in this study assumed a 3\% of live weight.

e. Feeding frequency, in this study it was assumed 2 times

f. The outflow rate of solid (k) from the rumen, in this study it was assumed $0.05 / \mathrm{h}$.

Determination of rumen characteristics and microbial protein production using in vitro digestibility test developed by Tilley and Terry (1963) with some modifications the procedure developed by Blummel et al. (1997). Rumen fluid used for testing the in vitro digestibility was taken from male Ongole cross breed that fitted with permanent canula in the rumen. A $500 \mathrm{mg}$ of sample inserted into the in vitro bottle and it was added $50 \mathrm{ml}$ of McDougal buffer solution and rumen fluid ( $\mathrm{pH} 6.9$ and temperature of $39^{\circ} \mathrm{C}$ ) with a ratio of 4:1. The bootles were saturared with $\mathrm{CO}_{2}$, then they were closed with a rubber and put into a water bath in $39^{\circ} \mathrm{C}$ of temperature for fermentation process. The bottle containing with a mixture of Mc Dougal and rumen fluid without samples was used as a blank.

All treatments were fermented for 24 hours. Shaking the bottle fermentors performed every 4 hours. Fermentation of each feed treatment performed on 4 bottles, 2 bottles fermentor which were used to measure the apparent degradability and the others were used to measure the true degradability. After 24 hours, the fermentation was stopped by immersion in ice water for 15 minutes. Apparent degradability was determined using two bottles that were centrifuged at $2500 \mathrm{~g}$ for $30 \mathrm{~min}$. Supernatant was used to measure $\mathrm{pH}$ (Hanna 301) then it was used for measurement of $\mathrm{NH}_{3}$ (preserved with $1 \mathrm{ml}$ of $\mathrm{H}_{2} \mathrm{SO}_{4} 1 \mathrm{~N}$ for $10 \mathrm{ml}$ sample) and individual VFA (acetic acid, propionic acid and butyric acid) was preserved with $\mathrm{HgCl}_{2}$ and $\mathrm{H}_{3} \mathrm{PO}_{4}$ as much as $1 \mathrm{ml}$ for 10 $\mathrm{ml}$ of sample. The residue was placed into a porcelain cup that had been weighed, then porcelain cup and the residue dried at $105^{\circ} \mathrm{C}$ for 12 hours followed by burning at a constant temperature of $600{ }^{\circ} \mathrm{C}$ for 2 hours to determine the degradability of organic matter.

True degradability determined using a sample that has been fermented in two other bottles. They reflux with $100 \mathrm{ml}$ of Neutral Detergent Solution (NDS) for 1 hour then they were filtered using crusibel filter. Crusible and the residue were dried at $105^{\circ} \mathrm{C}$ for 12 hours. Microbial biomass production (MBP) was calculated as the difference of digested weight of sample from the measurement of true and apparent degradability. Fermented organic matter in the rumen (FOM) is determined by calculating the organic matter content of feed multiplied by the organic matter degradability. $\mathrm{NH}_{3}$ concentration measurements were using steam destilasion while individual VFA (acetic acid, propionic acid and butyric acid) concentration measurements carried out according with the instructions of Bachrudin (1996). Concentration of $\mathrm{CH}_{4}$ and $\mathrm{CO}_{2}$ were estimated according to Van Soest (1994). The efficiency of microbial protein synthesis (EMPS) was determined as follows :

\section{$\operatorname{EMPS}(\mathrm{g} \mathrm{N} / \mathrm{kg}$ FOM $) \quad=(\operatorname{MBP}(\mathrm{g}) \times 7 \%) /$ FOM $(\mathrm{Kg})$}

Note : $7 \%$ is an average content of $\mathrm{N}$ in microbiall cell.

Variables that observed in this research were rumen fermentation characteristics $\left(\mathrm{pH}, \mathrm{NH}_{3}\right.$ concentrations, individual VFA, estimated the concentration of $\mathrm{CO}_{2}$ and $\mathrm{CH}_{4}$, the ratio of $\mathrm{C}_{2}: \mathrm{C}_{3}$, organic matter degradability, fermented organic matter in the rumen (FOM), microbial biomass production (MBP) and efficiency of microbial protein synthesis (EMPS). The study was used a randomized complete design with 3 treatments of synchronization index (SI). Three level of synchronization indexes were P1 (0.4); P2 (0.5) and P3 (0.6). Data were analyzed using a program GENSTAT 14.2 (2011).

\section{Result And Discussion}

Research 1. Determination of nutrients and degradation parameters of feedstuffs.

Nutrient content and degradation parameters of feedstuffs used in the experiment were presented in Table 1 and Table 2, respectively. The feedstuffs varied widely in term of nutrient content and the degradation parameters. The nutrient content of diets was presented in Table 3. 
Effect of synchronizing the rate degradation of protein and organic matter of feed base on rice by

Table 3: Nutrient content of feedstuffs in the experiment.

\begin{tabular}{|c|c|c|c|c|c|c|c|}
\hline Feedstuffs & $\operatorname{DM}(\%)$ & $\begin{array}{c}\text { OM } \\
(\% \text { DM })\end{array}$ & $\begin{array}{c}\text { CP } \\
(\% \text { DM })\end{array}$ & $\begin{array}{c}\text { EE } \\
(\% \mathrm{DM})\end{array}$ & $\underset{(\% \mathrm{DM})}{\mathrm{CF}}$ & $\begin{array}{c}\text { NFE } \\
(\% \text { DM })\end{array}$ & $\begin{array}{c}\text { TDN } \\
(\% \text { DM })\end{array}$ \\
\hline Rice straw & 43.75 & 78.27 & 5.73 & 1.99 & 26.93 & 34.01 & 47.63 \\
\hline Native grass & 26.71 & 78.30 & 10.50 & 1.35 & 21.42 & 45.03 & 55.00 \\
\hline Rice bran & 90.07 & 82.47 & 8.39 & 1.02 & 28.86 & 44.20 & 46.33 \\
\hline Cassava flour & 90.03 & 95.54 & 3.18 & 1.22 & 4.20 & 86.94 & 74.00 \\
\hline Coconut meal & 84.59 & 94.27 & 23.83 & 2.54 & 14.79 & 53.11 & 72.89 \\
\hline $\begin{array}{l}\text { Palm kernel } \\
\text { cake }\end{array}$ & 91.91 & 91.89 & 17.37 & 7.69 & 24.42 & 25.81 & 81.91 \\
\hline
\end{tabular}

Nutrient value (DM, OM, CP, EE, CF and TDN) of feedstuffs was varied. Dry matter of forage (rice straw and native grass) ranged from $26.86 \%$ (native grass) to $45.82 \%$ (rice straw). Dry matter value of concentrate varied between $88.19 \%$ (cassava) to $95.39 \%$ (palm kernel cake). Organic matter value varied between $76.97 \%$ (rice straw) to $93.58 \%$ (cassava flour). Crude protein value (CP) varied between $2.29 \%$ (cassava) to $24.91 \%$ (coconut meal). Value of ether extract (EE) varied between $1.25 \%$ (cassava) to $9.20 \%$ (palm kernel cake). Value of Total Digestible Nutrients (TDN) varied between $43.77 \%$ (rice bran) to $68.72 \%$ (cassava).

Table (2): The value of parameter degradation of organic matter (OM) and crude protein (CP)

\begin{tabular}{lcccccc}
\hline \multirow{2}{*}{ Feedstuffs } & \multicolumn{3}{c}{ OM } & \multicolumn{3}{c}{ CP } \\
\cline { 2 - 7 } & $\begin{array}{c}\mathrm{a} \\
(\%)\end{array}$ & $\begin{array}{c}\mathrm{b} \\
(\%)\end{array}$ & $\begin{array}{c}\mathrm{c} \\
(\text { fraction/hour) }\end{array}$ & $\begin{array}{c}\mathrm{a} \\
(\%)\end{array}$ & $\begin{array}{c}\mathrm{b} \\
(\%)\end{array}$ & $\begin{array}{c}\mathrm{c} \\
\text { (fraction/hour) }\end{array}$ \\
\hline Rice straw & 35.10 & 11.20 & 0.06 & 41.90 & 16.40 & 0.03 \\
Native grass & 18.10 & 41.60 & 0.08 & 32.30 & 40.60 & 0.16 \\
Rice bran & 22.60 & 21.60 & 0.20 & 41.30 & 37.40 & 0.25 \\
Cassava flour & 48.10 & 46.90 & 0.04 & 41.50 & 33.50 & 0.09 \\
Coconut meal & 24.40 & 63.30 & 0.07 & 29.62 & 70.40 & 0.01 \\
Palm kernel cake & 17.70 & 63.60 & 0.03 & 35.80 & 49.80 & 0.04 \\
Molasses & 100 & 0 & 0 & 100 & 0 & 0 \\
\hline
\end{tabular}

Research on the determination of the degradation parameters of rice straw by Chumpawadee et al. (2006), cassava conducted by Chumpawadee et al. (2006) and Chanjula et al. (2003) and copra meal conducted by Ibrahim et al. (1994) gives different results with the results in this study. According to Piao et al.(2012) the difference in the degradation parameter values the same feed ingredients caused by harvesting of feed ingredients, methods of measurement and factors specific to the measuring method is in sacco digestibility. 
Table (3): Feed formulation and nutrient content of dietary treatment

\begin{tabular}{cccc}
\hline Feedstuffs & P1 & P2 & P3 \\
\hline & & $(\%)$ & 20 \\
\hline Rice straw & 37.5 & 35 & 20 \\
Native grass & 2.5 & 5 & 26.5 \\
Rice bran & 10 & 10 & 16 \\
Cassava flour & 25 & 21.4 & 2.5 \\
Coconut meal & 12.5 & 12.5 & 15 \\
Palm kernel cake & 12.5 & 12.5 & 0 \\
Molasses & 0 & 3.6 & \\
Nutrient & & & 90.78 \\
DM (\%) & 92.80 & 93.05 & 89.50 \\
OM (\%DM) & 89.90 & 91.50 & 65.29 \\
TDN (\%DM) & 59.32 & 64.65 & 11.01 \\
CP (\%DM) & 10.52 & 10.66 & 19.67 \\
CF (\%DM) & 21.24 & 19.98 & 3.34 \\
EE (\% DM) & 2.82 & 2.97 & 0.6 \\
synchronization index & 0.4 & 0.5 &
\end{tabular}

Value of dry matter and organic matter respectively were $90.78 \%-93.05 \%$ and $89.50 \%-89.90 \%$. There was an increase in total digestible nutrient of feed due to increased synchronization index. Content of crude fiber of the diet decreased with the increasing of synchronization index. Improved synchronization index caused a decrease in the use of feed ingredients with high crude fiber content of rice straw. Ether extract content of the diet increased with the improvement in the synchronization index, it is because of the increased use of palm kernel cake and native grasses.

Table (4): Effect of synchronization index against concentration of acetic acid, propionic acid, butyric acid, $\mathrm{NH}_{3}$ and $\mathrm{C}_{2}: \mathrm{C}_{3}$ ratio

\begin{tabular}{lccccc}
\hline \multirow{2}{*}{ Variabel } & \multicolumn{3}{c}{ Dietary treatment } & SEM & P Value \\
\cline { 2 - 4 } & $\mathrm{P} 1$ & $\mathrm{P} 2$ & $\mathrm{P} 3$ & & 0.949 \\
$\mathrm{nyH}$ & 6.8 & 6.8 & 6.8 & 063 & 0.007 \\
Acetic acid (mM) & $18.04^{\mathrm{B}}$ & $12.77^{\mathrm{A}}$ & $11.59^{\mathrm{A}}$ & 0.728 & 0.020 \\
Propionic acid (mM) & $2.28^{\mathrm{A}}$ & $6.00^{\mathrm{B}}$ & $2.49^{\mathrm{A}}$ & 0.603 & 0.029 \\
Butyric acid (mM) & $2.00^{\mathrm{A}}$ & $4.01^{\mathrm{B}}$ & $3.7^{\mathrm{B}}$ & 0.347 & 0.013 \\
$\mathrm{C}_{2}: \mathrm{C}_{3}$ Ratio & $8.38^{\mathrm{B}}$ & $2.17^{\mathrm{A}}$ & $4.87^{\mathrm{A}}$ & 0.796 & 0.300 \\
$\mathrm{CO}_{2}$ & $12.58^{\mathrm{A}}$ & $13.89^{\mathrm{A}}$ & $11.97^{\mathrm{A}}$ & 0.765 & 0.031 \\
$\mathrm{CH}_{4}$ & $9.45^{\mathrm{B}}$ & $6.89^{\mathrm{A}}$ & $7.02^{\mathrm{A}}$ & 0.470 & 0.145 \\
$\mathrm{NH}_{3}$ (mg/l) & 50.71 & 50.04 & 52.27 & 0.787 & 0.773 \\
$\mathrm{OM}_{\text {degradability }}$ & 54.60 & 58.00 & 55.70 & 3.15 & 0.478 \\
FOM (g) & 0.22 & 0.24 & 0.23 & 0.013 & 0.373 \\
MBP (mg) & 53.60 & 57.90 & 59.60 & 2.01 & 0.133 \\
EMPS & 15.76 & 18.32 & 19.38 & 1.21 & \\
\hline
\end{tabular}

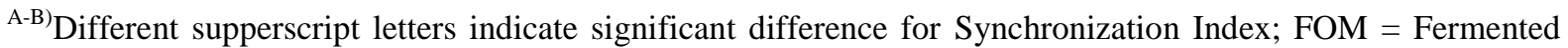
organic matter in the rumen; MBP = Microbial biomass production; EMPS = efficiency of microbial protein synthesis

Synchronization index did not affect the $\mathrm{pH}$ of the rumen fluid. Synchronization index affected to the concentration of acetic acid $(\mathrm{P}=0.007)$, propionic acid $(\mathrm{P}=0.020)$, butyric acid $(\mathrm{P}=0.029), \mathrm{CH}_{4}(\mathrm{P}=0.031)$ and ratio of $\mathrm{C}_{2}: \mathrm{C}_{3}$. Improved synchronization index led to a decrease in crude fiber in the diet (Table 3). This caused a decrease in acetic acid and $\mathrm{CH}_{4}$ (Van Soest, 1994). Based on this result, it was shown that the feed formulation according to synchronization index can improve feed efficiency and reduce global warming.

High concentrations of acetic acid led to a decrease in feed intake in vivo conditions. The formation of acetic acid also results in the formation of methane. Acetic acid formation produces hydrogen ions which are precursors for the formation of methane gas. Methane gas production on the use of agricultural waste as 
ruminant feed becomes a problem because methane is one of the greenhouse gases that contribute to global warming (Gworgwor et al., 2006)

Synchronization index did not affect the concentrations of $\mathrm{NH}_{3}$. Ammonia is a major and important source of nitrogen for microbial protein synthesis, the range of $\mathrm{NH}_{3}$ in this study was $50.04 \mathrm{mg} / 1-52.27 \mathrm{mg} /$ 1. This concentration is sufficient to support microbial growth that is $50 \mathrm{mg} \mathrm{N}-\mathrm{NH}_{3} / 1$ (Satter and Slyter, 1974). Concentration of $\mathrm{NH}_{3}$ in the rumen is influenced by the quantity, the solubility, rate of degradation, endogenous $\mathrm{N}$ sources, the use of $\mathrm{NH}_{3}$ by rumen microbes and recycling of $\mathrm{NH}_{3}$ (Nuswantara, 2009). Low levels of $\mathrm{NH}_{3}$ in the rumen can be caused higher microbial protein synthesis (Rotger et al., 2006). The level of use of $\mathrm{NH}_{3}$ for microbial protein synthesis is affected by the availability of energy. If the energy is limited then $\mathrm{NH}_{3}$ cannot be used in the synthesis of microbial protein that is indicated by accumulation of high amounts of $\mathrm{NH}_{3}$ (Henning et al., ; 1993; Mustvangwa, 2011).

Synchronization index did not affect to degradation of organic matter, organic matter fermented in the rumen, microbial biomass production and efficiency of microbial protein synthesis. Production of microbial biomass and efficiency of microbial protein synthesis tends to increase with the improvement of synchronization index. They have shown that the better synchronization index of the feed can increase the original microbial protein contribution to the host. The condition is expected to improve the productivity of livestock.This is consistent with results from Seo et al. (2010) who reported that improvement of the index of synchronization can increase the efficiency of protein synthesis and fermentation of microbes in the rumen. The impact of the improvement of the efficiency of microbial protein synthesis is a decreased production of methane (Leng and Preston, 1987)

\section{Conclusion}

Improvement of synchronization Index on feed based on rice by products causing

1) a decrease in the concentration of acetic acid, $\mathrm{CH}_{4}$ concentration, the ratio of $\mathrm{C}_{2}: \mathrm{C}_{3}$ so it can reduce global warming

2) increase on the efficiency of microbial protein synthesis. This can have an impact on improving livestock production.

\section{REFERENCES}

[1] Anonimous, Agricultural statistics (Ministry of agriculture Republic of Indonesia, 2013)

[2] AOAC, Official methods of analysis. 15 th edition (Association of official analytical Chemist, Arlington, Virginia.USA, 2009)

[3] Bahchrudin, Z. Pengaruh $\mathrm{pH}$ dan asam lemak mudah terbang (Volatile Fatty Acids-VFA) Cairan rumen dengan gas khromatography (kursus singkat teknik evaluasi Pakan Ruminansia). (Fakultas Peternakan Universitas Gadjah Mada. Yogyakarta, 1996)

[4] Blummel, B.Y., H. Steingas and K. Becker, The relationship between in vitro gas production in vitro microbial biomass yield and $15 \mathrm{~N}$ incorporation and its implication for the prediction of voluntary feed intake of roughages. British Journal of Nutrition. 77,1997, 911-921.

[5] Chanjula, P., M. Wanapat, C. Wachirapakorn, S. Uriyapongson and P. Rowlinson, Ruminal degradability of tropical feeds and their potential use in ruminant diets. Asain Australian Journal of Animal Science, 16 (2),2003,211-216.

[6] Cole, N. A. and R. W. Todd. Opportunities to enhance performance and efficiency through nutrient synchrony in concentrate-fed ruminants. Journal of Animal Science. 86(E. Suppl.), 2008, E318-E333.

[7] Czerkawski, J.W, An Introduction to Rumen Studies (Oxford, Pergamon Press, 1986)

[8] Chumpawadee S., K. Sommart, T. Vongpralup and V. Pattarajinda. Effect of synchronizing the rate of dietary energy and nitrogen release on ruminal fermentation. microbial protein synhesis. blood urea nitrogen and nutrient digestibility in beef cattle. Asain Australian Journal of Animal Science 19(2), 2006,181-188.

[9] GenStat, GenStat Release 14 Reference Manual (VSN International, 5 The Waterhouse, Waterhouse Street. Hemel Hempstead, Hertfordshire HP1 1ES. UK, 2011)

[10] Gworgwor, Z. A.,T.F. Mbahi and B Yakubu, Environmental Implications of Methane Production by Ruminants: A review.Journal of Sustainable Development in Agriculture and Environment 2(1), 2006, 1-14.

[11] Hartadi H, Reksohadiprodjo S, Tillman A.D, Tabel komposisi pakan untuk Indonesia. (Gadjah Mada University, Yogyakarta, 1986)

[12] Henning, P.H., D.G. Steyn and H.H. Meissner, Effect of synchronization of energy and nitrogen supply on ruminal characteristics and microbial growth. Journal of Animal Science. 71(9), 1993:2516- 2528.

[13] Ibrahim, M.N.M, Feeding Tables For Ruminants in Sri Lanka (Animal Feed Advisory Commite, Veterinary Reserach Institute. Gannorwa. Sri Lanka, 1988)

[14] M.N.M. Ibrahim, S. Tamminga, G. Zemmelink, Degradation of tropical roughages and concentrate in the rumen, Animal Feed Science and Technology 54, 1995, 81-92

[15] International Feed Resources Centre. Neway Excel: a curve fitting program. (International Feed Resources Centre, 2004)

[16] Martawidjaja, M, Pemanfaatan Jerami Padi sebagai Pengganti Rumput untuk Ternak Ruminansia Kecil. Wartazoa 13(3), 200, 119127. Puslitbang Peternakan. Badan Litbang Pertanian.

[17] Mustvanga, T, Focus on efficiency: Coordinating dietary starch and protein utilization in the rumen. WCDS advances in dairy technology. 23, 2011, 137-150.

[18] Nuswantara LK. 2009. Parameter Fermentasi rumen pada kerbau yang diberi pakan tunggal glirisidia, jerami jagung dan kaliandra. Seminar Nasional kebangkitan Peternakan.

[19] Seo, J.K. ,J. Yang, H.J. Kim, S.D. Upadhaya, W.M. Cho and J.K. Ha, Effect of Synchronization of Carbohydrate and Protein Supplay on Ruminal Fermentation. Nitrogen Metabolism and Microbial Protein Synthesis in Holstein Sterrs, Asain Australian Journal of Animal Science. 23(11), 2010, 1455 - 1461. 
[20] Ørskov. E. R. \& I. McDonald.1979. The estimation of protein degradability in the rumen from incubation measurement weighted activating to rate of passage. Journal of Agricultural. Science. 92 : 499-503.

[21] Piao MY. H J Kim. JK Seo. TS Park. JS Yoon. KH Kim and JK Ham, Effects of synchronization of carbohydrate and protein supply in total mixed ration with korean rice wine residue on ruminal fermentation. nitrogen metabolism and microbial protein synthesis in holstein steers. Asian Australian Journal of Animal Science. 25(11), 2012, 1568-1574

[22] T.R. Preston and Leng R.A, Matching Ruminant Production System with Available Resources in the Tropic and Sub Tropics.(Penambul Books. Armidale, Australia, 1987)

[23] Richardson, J.M.R., G.Wilkinson and Sinclair, L.A, Synchrony of nutrient supply to the rumen and dietary energy source and their effects. Journal of Animal Science. 81(5),2003,1332-1347.

[24] Rotger, A., A. Ferret, S. Calsamiglia and X. Manteca, Effects of non structural carbohydrates and protein sources on intake apparent total tract digestibility and ruminal metabolism in vivo and in vitro with high-concentrate beef cattle diets. Journal of Animal Science 84, 2006,1188-1196.

[25] Satter LD and Slyter LL. Effect of Amonia Concentration on Rumen Microbial Production in vitro. British Journal Nutrition. 32, 1974,194-208.

[26] Sinclair, L.A., P.C. Garnsworthy, J.R. Newbold and P.J. Buttery, Effect of synchronizing the rate of dietary energy and nitrogen release on rumen fermentation and microbial protein synthesis in sheep, Journal of Agricultural Science.120, 1993, $251-263$.

[27] Tilley J.M.A. and R.A.Terry, A Two Stage Technique for the in vitro Digestion.of Forage Crop. Journal of British Grassland Society. 18, 1963, 104-111.

[28] Utomo. R. 2004. Review Hasil - Hasil Penelitian Pakan Sapi Potong. Wartazoa 14: 116-124. Puslitbang Peternakan.Badan Litbang Pertanian

[29] Van Soest, P.J, Nutritional Ecology of the Ruminant (Cornel University Press, London, 1994) 